\title{
LANDSCAPE-ECOLOGICAL INTERPRETATION AND APPLICATIONS OF LANDSCAPE SURVEY RESULTS FOR OPTIMAL LAND USE
}

\author{
LUBICA ZAUŠKOVÁ
}

Department of Geography, Geology and Landscape Ecology on Faculty of Natural Sciences of Matej Bel University, Tajovského 40, 97401 Banská Bystrica, Slovak Republic; e-mail: 1.zauskova@seznam.cz

\begin{abstract}
Zaušková L: Landscape-ecological interpretation and applications of landscape survey results for optimal land use. Ekológia (Bratislava), Vol. 33, No. 3, p. 252-258, 2014.

Landscape-ecological multidisciplinary approach is turning out to be the only suitable solution for the problem of land-use optimisation. The article puts forward a landscape-ecological methodology of landscape-ecological carrying capacity (LCC) evaluation and accounts for its interconnection with sectoral surveys. Primarily it is an interpretation of survey results of the forest ecology in forestry and the complex soil survey in agriculture within the methods of LCC. By application of the results, the process of LCC evaluation will be accelerated and remedial measures will be provided more efficiently. The result of an application of the methodics will be suitable land use in conformity to landscape potential, while landscape-ecological limits are respected. The article calls attention to the fact that LCC methods should be considered within the planning of land use of forest and agricultural landscape on the basis of the entire gravitational unit - watershed.

Key words: sustainable development, optimal land use, landscape-ecological carrying capacity, forestry, multifunctional agriculture, land surveys.
\end{abstract}

\section{Introduction}

According to $\mathrm{Wu}$ (2006), landscape ecology has successfully demonstrated the power of the landscape scale as an analytical framework for sustainability science. Drdoš (1996) declared that landscape ecology's ultimate goal is environmental protection and achieving this goal using different investigational methods is part of its interdisciplinary nature. Landscape ecology as a discipline (as evidenced by the analysis of papers in Landscape Ecology (Andersen, 2008)) has in some aspects become more unified as the two contrasting and complementary perspectives have become more integrated. Landscape-ecological multidisciplinary approach, characterised by a cross-department and spatial perspective to solve problems of landscape related to optimal land use and achieving sustainable development, manifests itself as most suitable from a long-term viewpoint. It is also demonstrated by the fact that the landscape-ecological planning (LANDEP) methodology (Ružička, Miklós, 1982) was adopted in the Conference on Environment and Development (in Rio de Janeiro, 1992) in the internationally accepted document Agenda 21. 
Later, the methodology of landscape-ecological carrying capacity (LCC) was linked to the LANDEP methodology (Hrnčiarová et al., 1997), formed by a group of Slovak landscape ecologists. The aim of this methodology is to secure an ecologically optimal land use. LCC evaluation forms an obligatory part of various long-accepted legislative directives in the Slovak Republic (Law No. 17/1992 on environment, Law No. 127/1994 and new codified Law No. 24/2006 on environmental impact assessment). Later, the LCC methodology became a base for landscape-ecological plan within building act (Law No. 237/2000) and water act (Law No. 364/2004); within their frame is integrated landscape and river basin management secured. Landscape-ecological planning began as one of the pillars of the national programme of European Landscape Convention Implementation (2000).

\section{Landscape-ecological carrying capacity}

In sense of the LCC methodology evaluation (Hrnčiarová et al., 1997), LCC is comprehended as a synthetic purpose landscape character, which expresses a degree of acceptable (suitable) land use by anthropogenic activities, while retaining its natural attributes, processes and relations and environmental quality. The object of ecological carrying capacity evaluation is the landscape and its elements, or more precisely, components of abiotic, biotic and socioeconomic character, which are in mutual relation.

Methodic procedure consists of landscape-ecological analysis of territory and elements belonging to primary landscape structure, least affected by man (geological-substrate complex, soil, relief, air, water, potential vegetation). Further, there is an analysis of secondary landscape structure, or more specifically present landscape structure, which is a result of human activities (land-use forms, real vegetation and fauna, newly formed agriculture techniques, etc.), as well as an analysis of tertiary landscape structure focused on positive and negative socio-economic phenomena (particularly nature, landscape and natural resources protection concerns, and also stress factors such as air-, water-, soil-pollution zones, etc.). Following the landscape-ecological analysis is the landscape-ecological synthesis that is as a delimitation and classification of areas with more or less equal landscape-ecological conditions, which are called types of landscape-ecological complexes. Attributes of the landscape-ecological complex type determine its suitability (and carrying capacity as well) for human use. The next phase of methodic procedure is the landscape-ecological interpretation, which results in three purpose landscape attributes: landscape vulnerability, present load and ecological significance of landscape. Landscape vulnerability is a purpose landscape attribute that expresses presumed landscape reaction to external disturbing effects. The present load of landscape expresses area load by stress factors (primary and secondary) and the ecological significance is a purpose of landscape attribute determining the scale of securing the positive landscape ecological processes and functions. The elements that create favourable propositions for functioning of ecosystem processes and for retaining favourable conditions for regeneration and for gene pool, ecological stability and biodiversity at landscape renewing and on renewing of natural processes are considered as ecological significant elements. The above-mentioned attributes enter into the process of evaluation in the form of limits. Landscape-ecological evaluation is a process of determining the suitable public activities for various ranges. It is considered as 
a confrontation of demands of several activities with landscape-ecological conditions. The last step of methodology, landscape-ecological proposition, is a selection of suitable activities. Also, an estimate of the three levels of ecological carrying capacity (suitable use, medium suitable and unsuitable land use) is made as well as measures for the reduction of negative human activities are proposed.

\section{Interpretation of forest ecology survey results in methodology of the LCC}

A complex forest status determination in the Slovak Republic is realised by the forest ecology survey. Its goal is to identify the state of forest ecosystems, to analyse forest management conditions from the viewpoint of forest ecosystems ecological stability, to predict their development, to set goals and ecological principles of management and to suggest ecological measures. The forest ecology survey contains a complex survey of forest ecosystems concerning their status, damage, changes and potential threat (www.forestportal.sk). After finalisation of the ecological survey data, they are transformed into forest management plan (FMP).

The FMP is a tool which should provide guidelines for systematic forest management. It contains several parts. The most important are the description of forest stands and the plan of management measures. This part contains a large amount of data concerned with forest stands (spatial disposition forest units), which together with forest maps brings data and advices to the forest manager, and also observes other functions (for forestry administration authorities, environment administration authorities, the forestry information centre, etc.).

Within the application of LCC methodology, basic forest typological units are first used in landscape-ecological synthesis of primary landscape structure, which were created on the basis of equal, or more precisely similar site conditions. Based on their distribution and order, specific ecological grids are arising (according to Vladovič, 2003), expressing the potential of natural forest resources and allowing areal stratification from the viewpoint of natural conditions. Thus, they are a basis for the functional forest typification and its sequent categorisation. The present landscape structure is characterised, on the one hand, by real vegetation on the basis of forest stands management groups, which according to Hančinský (1977) are a reflection of present forest species composition, and a spatial forest species distribution, and, on the other hand, by present forest land use on the basis of functional forest types.

The goal of the LCC methodology is to assess present land-use suitability, while respecting landscape-ecological limits and natural resources regenerative capacity. In forestry terminology, this means a re-evaluation of functional forest types mentioned in present FMP on the basis of other landscape-ecological limits (resulting from present load, vulnerability and ecological significance of landscape), which were not considered in the process of creation of functional types. They were undervalued because of the economic effect resulting from the primary and prevailing production functions of forests. At the same time, it is a mutual confrontation of present forest land use and landscape-ecological conditions, which are represented by surface disturbance degrees due to forest roads density, clear-cuts, level of forest disturbance by windthrow, level of threat of forests by damaging factors (abiotic, biotic and anthropic), by level of erosion threat due to surface run-off, level of site-ecological suitability, ecological stability level, nature and water resources protection level, etc. 
Functional forest types, expressing a predominating way of forest management on a specific area, have a key role in forest classification based on the function of production forests, protective forests and forests of special determination, which influence the management of forest, that is, on the present forest land use. Re-evaluation of functional forest types using the LCC methodology will often mean a crucial change in favour of ecological and environmental forest functions (particularly soil-protection and hydric forest functions). The reevaluation of functional forest types will be done with regard to adjacent landscape within a river basin (e.g. with relation to securing sufficient quality drinking water, flood protection, avalanche and landslide protection, etc.).

\section{Results of complex soil survey interpretation and derived categories in LCC methodology}

Within landscape-ecological analyses, respectively syntheses the classification system of bonited soil-ecological units (BSEU) is used in the Slovak Republic. BSEU are the most homogenous soil and ecological units of boniting information system. They represent main soil-climatic units that are divided into categories according to their slope inclination, slope orientation, skeletal code of soil, soil depth and texture of surface soil horizon. Every parcel of land is characterised by parameters of soil-ecological properties expressed by the so-called bonited soil-ecological units. These units also correspond to normative data on agriculture plants production, which can be planted in the given natural conditions and common agricultural engineering, as well as normative data on inputs, which serve for soil value calculation (Džatko, 1976).

Within the agricultural landscape, the main interest is focused on the production potential of soils. The typological-production categories of agricultural soils are a significant interpreted category in relation to LCC assessment (Džatko, 2002), which were created on the basis of detailed knowledge on spatial structure of soil production potential, including a number of analysis results within the soil-ecologic unit relations and the production of main crops. Contrary to the point values, the BSEU also indicate sustainable relations between BSEU characteristics and ways of use of their potential. From the point of view of LCC evaluation, typological-production categories represent a potentially suitable usage of agricultural landscape and are considered as one of the basis of multifunction agriculture principles application.

Present agricultural landscape structure (and its present land use) does not always correspond to typological-production categories, which are related to agriculture decline after 1989 in Slovak Republic. With the changing of owner-occupied relations redounded to agriculture soil occupation for build-up and to spontaneous grasslands and pastures in growth (succession) by non-forest tree and shrub vegetation, a new phenomenon occurred in the landscape - the problem of abandoning of the agriculture landscape, which makes us rethink about its target quality.

A reform since 2003 brings a chance for change within agriculture landscape usage. This reform has relinquished the then structure of direct payments on agricultural production and it applied the so-called unbound payments on historic or regional principles, wherewith there is continuation of agricultural land use without duty. Multifunction agriculture has be- 
come an ideological base of the European agrarian policy and its reforms, i.e. an action that fulfils multiple functions (economic, ecological and social). A key point here is the fact that agriculture is more than just production and sale of commodities. There are also side benefits (externalities) from agriculture that contribute, according to Miština (2006), to viability of life in rural areas (sustaining families of farmers, rural employment and cultural heritage), biological diversity, recreation, bioenergy, landscape aesthetics, quality and food safety. This has led to new perspectives on production evaluation. There are no steps taken to build on these perspectives, but just specific agro-environmental conditions are met.

Use of multifunction agriculture comes out from typological-production categories or its sequential implementation into primary and secondary soil funds. The secondary soil fund (secondary agriculture soil), particularly, can be used temporarily for purposes other than food. However, this will not lead to its degradation (character and attributes will remain practically unchanged). It is possible to utilise this land for alternative agriculture use such as for the production of bioenergy, raw material, reforestation, sports, recreation and tourism activities; part of it can also be used for occupation.

Land-use optimisation in the process of evaluation is a confrontation of landscape-ecological conditions and socio-economic demands for use. It is necessary to consider the limitations resulting from three key LCC criteria (landscape vulnerability, present load and landscape ecological significance). These limit intensive agricultural activities. From the viewpoint of vulnerability, the land is vulnerable to erosion by water and wind as well as extreme weather conditions such as drought and floods (Zaušková, Midriak, 2008). Erosion by water is a permanent process that results in the reduction of soil profile, loss of fine earth and nutrients, degradation of soil texture and structure and degradation of water regime, which in turn lead to a decrease in natural soil fertility. Rainstorms, as a result of extreme climatic changes, pose a serious threat to soils by minimum slope inclination, because of the kinetic energy of the bombarding raindrops. It is necessary to take preventive measures against erosion by water through the selection of planted crops, as well as by exercising anti-erosion measures. Erosion by wind affects the soil by disturbing soil surface by abrasion, carrying away eroded parts (deflation) and by accumulation of these parts in another place. It is a degradation process that not only causes loss to agriculture lands - soil transport, loss of fertilisers, seeds and demolition of agriculture crops but also causes sedimentation of routes, ditches, water flows, channels, sand banks and air pollution. Drying effect of wind also affects soil negatively. Drought is a limiting factor for crops. Dry periods within the vegetation season significantly affect the water consumption of plants.

From the standpoint of ecological significance of landscape, limits due to legal regulations and conventions, concerning nature and protection of natural resources (Law No. $543 / 2002$ on nature and landscape protection, Natura 2000, Law No. 364/2004 on waters, Ramsar convention, etc.), are relevant.

Limits resulting from present load are related particularly to anthropogenic stress factors (e.g. land occupation for build-up, pipelines location, power lines, exhaust gases effects, influence of road salts, soil degradation caused by unsuitable land management, the size of exploitation ranges, etc.).

In proposals for agricultural land-use optimisation, it is necessary to come out from presumption (from supply of resources and space potential) - typological-production soil 
categories, i.e. from agriculture landscape potential. Nevertheless, it is also necessary to consider the limits due to environment sensitivity, as well as those from legislative norms, which determine the so-called absolute potential, i.e. the rate of tolerable land use, thereby ensuring that there is no disturbance to landscape's space ecological stability and no ineligible changes to landscape. Subsequently, it is necessary to compare the state of present land use with the absolute potential and to propose such measures to the present land-use state to approach a suitable land use.

\section{Conclusion}

The landscape-ecological complexes are a result of application of LCC methodology, which are not identical with planning units within forestry or agriculture. It is hard to support recommendations to its evaluation to practice. Therefore, it is desirable to increase mutual cooperation between foresters, farmers, water managers and landscape ecologists on the basis of agriculture. Landscape ecologists should use results of specific surveys which are realised in forestry, agriculture and water management more often (Zaušková, 2001, 2003). Experts of these fields should apply a landscape-ecological (holistic) approach by planning their priorities within their departments. This approach is considered comprehensively under the European Union directives.

Nevertheless there are efforts to exert the functionally integrated forest management principles within forestry and the multifunction principles within agriculture; however, efforts are futile concerning mutual interaction between forest and agricultural landscape and its influence on watershed. There is complex solving of problems within a gravitational unit - river basin missing.

The survey information not only accelerates the process of evaluation of the methodics of LCC, but a new interpretation of the data also results in better evaluation of efforts that were in place to address the issue, and retroactively it also benefits (from standpoint of new point of view) separate departments (Zaušková, 2007).

Acknowledgements

This work was supported by the agencies for supporting research and development of the Slovak Republic under contract No. APVV-0591-07.

\section{References}

Andersen, B.J. (2008). Research in the journal Landscape Ecology, 1987-2005. Landsc. Ecol., 23, 129-134. DOI: 10.1007/s10980-007-9187-2.

Agenda 21 and Indicators of Sustainable Development (in Slovak) (1996). Bratislava: MŽP SR.

Drdoš, J. (1996). A reflection on landscape ecology. Ekológia (Bratislava), 15(4), 369-375.

Džatko, M. et al. (1976). Characteristic of bonite soil-ecological units of the Slovak Republic (in Slovak). Bratislava: Príroda.

Džatko, M. (2002). Evaluation agricultural soil/land productivity and agricultural land use potential of regional of Slovakia (in Slovak). Bratislava: VUPOP.

European landscape convention (2000). Florencia.

Hančinský, L. (1977). Forest typology in operating practice (in Slovak). Bratislava: Príroda.

Hrnčiarová, T. et al. (1997). The ecological carrying capacity: Methodology and its application on 3 target areas 
(in Slovak). Part I-IV. Bratislava: MŽP SR, ÚKE SAV.

Miština, T. (2006). Externalities in plant production (in Slovak). In G. Blaas (Ed.), Multifunkčné postavenie a trvalo udržatelný rast polnohospodárstva a lesníctva (pp. 56-61). Zborník SAPV. Nitra.

Ružička, M. \& Miklós L. (1982). Landscape-ecological planning (LANDEP) in the process of territorial planning. Ekológia (ČSSR), 1(3), 297-312.

Vladovič, J. (2003). Regional bases and principles for the assessment of tree species composition and ecological stability of forests in Slovakia (in Slovak). Lesnícke štúdie 57. Bratislava: Príroda.

Zaušková, L. (2001). Interface between landscape-ecological and forestry methodological approaches in landscape ecology (in Slovak). In R. Midriak (Ed.), Smery rozvoja a výučby aplikovanej ekológie (pp. 163-167). Banská Štiavnica: FEE.

Zaušková, L. (2003). Ecological carrying capacity of forest landscape and soil conservation. (Case study from the catchment of Hriňová Drinking Water Reservoir, the Polana Biosphere Reserve). Vedecké štúdie 1/2003/A. Zvolen: TU vo Zvolene.

Zaušková, L. (2007). Forest management planning in the context with the European Landscape Convention (in Slovak). Lesnicky Časopis, 53, 145-152.

Zaušková, L. \& Midriak R. (2008). Multifunctional agriculture as an alternative of sustainable development of the agricultural landscape (in Slovak). In Z. Izakovičová (Ed.), Kultúrna krajina ako objekt výskumu v oblasti trvalo udržatelného rozvoja (pp. 61-67). Smolenická výzva IV. Bratislava: ÚKE SAV.

Wu, J. (2006). Landscape ecology, cross-disciplinarity, and sustainability science. Landsc. Ecol., 21, 1-4. DOI: 10.1007/s10980-006-7195-2.

http://www.forestportal.sk

Law No. 17/1992 on environment (in Slovak).

Law No. 127/1994 on environmental impact (in Slovak).

Law No. 237/2000 building act (in Slovak).

Law No. 543/2002 on nature and landscape conservation (in Slovak).

Law 364/2004 on waters (in Slovak). 